\title{
Theme IV: The Transition to Socialism
}

A large number of participants felt that this topic was central to their concerns, for their work, whether in research, developing policy options or in encouraging grassroots women's organisation, had led them to question the capacity of the present social order to ensure women an equal role in society. At the same time, existing socialist societies present contradictory evidence as to whether a change in relations of production is sufficient to guarantee women either greater equality of opportunity, access to political power, or social esteem.

The plenary paper by Croll and Molyneux ${ }^{1}$ was an attempt to examine policies and attitudes of socialist countries towards the problem of women's subordinate socio-economic position. The paper began with a discussion of how to conceptualise socialism and argued that it was a transitional form to be distinguished from communism. Certain criteria were specified which would enable a distinction to be made between countries in which socialism is more or less advanced, according to the extent to which they had been able to meet, or are attempting to meet, these criteria.

The paper singled out three assumptions which underlie socialist policies affecting women:

- that the determination of women's oppression is social rather than biological or psychological;

-that limitations to women's full equality are objective (legal, educational and economic) rather than subjective;

-that the family is the basic cell of society.

The main argument of the paper was that while there had been a number of progressive measures, particularly in the fields of legislation and entry into production and education, policies had nonetheless failed to take adequate account of several factors of critical importance to the emancipation of women.

The first area is that of the sexual division of labour both in the domestic sphere and in production. Here any analysis should include investigation of the re-allocation of resources required to resolve the conflict between the public and

1 The Transition to Socialism by Elizabeth Croll and Maxine Molyneux. domestic demands of women. During the transitional phase, competition for scarce resources may cause women's issues to compete with other priorities. Without careful planning and a high degree of consciousness, short-term priorities established during the initial periods of socialist construction may easily become routinised as longterm policies. This may mean that many socioeconomic functions continue to devolve upon individual households, and, because of the prevailing sexual division of labour, upon women.

The second area was that of ideology and its relation to material structures in processes of social change. Despite the erosion of the more extreme forms of sexual prejudice, the notion of female inferiority has survived radical changes in material and social circumstances. The tendency within the socialist states to attribute this almost solely to ideological factors was questioned and the existence of certain material structures given as an alternative explanation.

The tension that has surrounded women's organisations set up by the Revolutionary Party was the third area for analysis. Such tension often arises as a result of the women's organisation's dual role as an instrument of the Party and as a pressure group encouraging women to articulate their needs. This contradiction is inherent in the establishment of gender-specific organisations in a period of intense class struggle characteristic of the transition to socialism. The ambiguity that has surrounded the consolidation of such women's organisation's methods of work and appropriate arena of activity was felt to have affected their ability to forward their own interests as well as to maintain their autonomy.

Finally the plenary paper questioned the extent to which obstacles to the full emancipation of women derive from inadequacies in the implementation of policies, or from deficiencies in the theory itself. This point formed the main basis for the discussion of the paper, and many of the participants were able to draw on their own experience in debating these important issues. One strongly expressed view was that in the period of transition it may be wrong to expect equality to be the principal goal in the face of the necessity for rapid economic development. Others disagreed, arguing that the difficulties of socialist construction should not preclude such considerations, and indeed it was vital to the character of the emerg- 
ing society that such questions as equality and democracy should not be suppressed, even in the period prior to the Revolution. Other points such as how to conceptualise the nature of the socialist state and the interests it represents were raised and elaborated in the discussion following the individual papers.

$\mathrm{Croll}^{2}$ highlighted the main points of the legal, economic, political and organisational strategies introduced in Russia and in China to end the subordination of women, the most crucial component being the entry of women into the labour force. A number of economic and educational policies introduced by each government to encourage women to enter employment were examined, together with measures to enable women to control their own fertility and create conditions favourable to child care. The means by which women's organisations helped to eradicate traditional norms and popularise new legal rights was assessed. The paper concludes that while women have received a share of the benefits derived from the introduction of socialist practices, many of these are only partial, and in certain areas achievements fall far short of stated goals.

The obstacles inhibiting the redefinition of women's roles were categorised into three main areas. First, the relation of ideological to economic variables in redefining the position of women; secondly, the extent to which the individual household still acts as a base unit of production and consumption; and lastly, the ambiguous position of women's organisations.

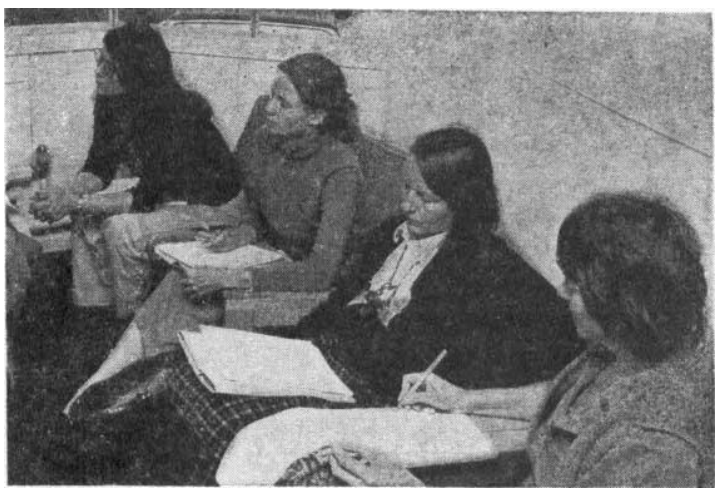

The discussion noted that the persistence of domestic work as women's primary responsibility

2 Problems and Practices: The Case of the Soviet Union and China by Elizabeth Croll. was a feature common to both capitalist and socialist societies, due to the contradiction between the State's economic need to maintain the family as a reproductive unit, and its ideological emphasis on changing gender relations. The emphasis on ideological structures to some extent masked the materiality of these relations, and the fact that changing gender relations might threaten family structure, throwing the burden of reproduction on to the State.

Lastly it was noted that the number of women in political decision-making in the two societies was very limited, and that campaigns to eradicate notions of women's inferiority appeared to have had only limited success.

In First-Dilic's paper ${ }^{3}$ the process in Yugoslavia by which agriculture has become increasingly feminised is described. As a result of rapid industrialisation and urbanisation and the concomitant migration of men and young unmarried women to the cities, peasant wives and mothers have become the mainstay of the agricultural sector. This has meant that they now undertake work which requires the lowest qualifications, provides the lowest income and has no 'social reputation'. At the same time they still have to perform their tradition domestic chores which effectively means they have no time to participate in other social and political activities.

In the discussion it was noted that peasant women not only have to cope with increased agricultural duties but also an upgrading of domestic tasks. Social pressures to improve standards of housework and child-care, without concomitant services, made their burden even greater.

Two papers on the People's Democratic Republic of Yemen (PDRY) considered changes in the position of women since Independence from Britain in 1967. Both discuss state intervention to improve women's position and to erode customary discrimination and purdah restrictions. Hibatulla ${ }^{4}$ outlined the main areas of such intervention: legal reform, education, political representation and entry into employment. Molyneux ${ }^{5}$ evaluated these areas of state policy, arguing that given the serious social and economic difficulties the PDRY has faced, the achievements have been considerable. Nonetheless a number of problems remain: first,

3 The position of the Woman Farmer in the Socialist Federal Republic of Yugoslavia by Ruza First-Dilic.

4 The Development of the Struggle of Yemeni Women over the Last Two Decades by Zahra Hibatulla.

5 Women and Socialism: The case of the People's Democratic Republic of Yemen by Maxine Molyneux. 
women have been incorporated into the labour force (mainly to inferior positions within it) but there has been no restructuring of responsibilities in the home. This, coupled with the inadequacy of child-care facilities also noted by Hibatulla means the institution of the double day for women.

Secondly, Molyneux noted that the political representation of women lacks any autonomy from the overall Party structure and may not adequately serve the interests of women. This was compounded by the absence of any explicitly feminist current in the Liberation struggle. Third, there was the problem of the persistence of ideologies of female inferiority, related to the persistence of untransformed material relations.

The sources of women's oppression in Mozambique inherited from the pre-colonial and colonial periods were examined in Ong's paper ${ }^{6}$ which went on to look at the role of women within the armed struggle. Through their own organisations, established in the liberated zones, women both participated in the revolutionary process and gained a growing consciousness of their subordinate position and of how they could fight this oppression within the framework of the liberation struggle. The paper noted both the successes and the difficulties which accompanied this process. Although women did perform many of the same roles as men and contributed to the war effort, the women's organisation lacked both an adequate organisational structure and experienced personnel, inhibiting both policy formulation and its implementation.

After 1975 the need for a fundamental shift from the liberation struggle to consolidating the revolution and establishing socialism led to more ideological forms of struggle. Here the lack of political cadres has presented serious problems. In the women's organisations a new emphasis on production and reproduction is forming the basis for the first stage of the political education of Mozambican women.

Discussion of the transition to socialism was both varied and wide ranging. The persistence of inadequate provision for the socialisation and equalisation of domestic tasks within socialist societies was a matter for concern. While there are difficulties in socially representing the labour input of the domestic sphere, it was agreed that this is an area which is normally ignored or represented as an ideological problem. How much this was due to

6 Women in the transition to Socialism by Ong Bie Nio. the difficulties of the transitional process was also considered.

Concern was expressed by participants to understand why no new concept of the family had emerged under socialism. The discussion ranged around the question of the nature of the social formations prior to the adoption of socialism, the difficulties imposed by the economic conditions characteristic of under-development and decades of imperialist exploitation, the question of investment strategies and the need for capital accumulation prior to massive social investment in socialising the content of many of women's roles.

Much of the discussion centred on themes raised in other sessions; particularly those in the workshop on marriage, family and class. In relation to socialism the issues which seemed of particular relevance were:

-how to understand the acceptance of the institution of marriage in socialist states;

-how far the maintenance of the nuclear and patrilocal family is responsible for maintaining women in a subordinate position in the home;

- to what extent the family form inhibits women's sexuality;

-how to understand the emphasis placed by socialist states on heterosexual monogamy.

Participants fully recognised the fact that class and gender interests are not always complementary, particularly during periods of intensive socialist reconstruction when priority may be accorded to economic development rather than to the elimination of class and gender inequalities. There was discussion of how the persistence of inequalities might be understood in terms of the overall socio-economic and political conditions of developing socialist countries, and of how the existence of a sexual division of labour allocating women to inferior occupations can be understood. Is it just a temporary measure adopted by socialist countries in the face of practical difficulties? Why has it not been raised as a major issue in the socialist countries themselves and why have women apparently colluded in it?

Lastly, the conference discussed the persistence of ideologies justifying gender inequalities, or the complementarity of gender roles. The degree to which women participated in the revolutionary struggle prior to the take-over of power was felt to 
be an important factor here, as was the role of women's organisations in the post-revolutionary phase and its relation to the revolutionary party. Unfortunately, too little information was available for an adequate understanding of this critical area, but participants underlined its importance for developing any theory of a socialist strategy of development. 